\title{
Al-Ghazali and the Golden Rule: Ethics of Reciprocity in the Works of a Muslim Sage
}

\section{Justin Parrott}

To cite this article: Justin Parrott (2017): Al-Ghazali and the Golden Rule: Ethics of Reciprocity in the Works of a Muslim Sage, Journal of Religious \& Theological Information, DOI: 10.1080/10477845.2017.1281067

To link to this article: http://dx.doi.org/10.1080/10477845.2017.1281067

\section{Published online: 09 Mar 2017.}

Submit your article to this journal $\square$

Q View related articles $\asymp$

View Crossmark data \lceil 


\title{
Al-Ghazali and the Golden Rule: Ethics of Reciprocity in the Works of a Muslim Sage
}

\author{
Justin Parrott \\ New York University in Abu Dhabi, Abu Dhabi, United Arab Emirates
}

\begin{abstract}
The golden rule ("do unto others as you would have them do unto you") has become an important focal point in modern interfaith dialogue with Muslims. As an ethical concept, it can be transferred, more or less, intact between different religions and philosophies, with or without the authority of scripture. This article aims to assist interfaith efforts with Muslims by examining the use of the golden rule in the works of 12th century Muslim mystic, ethicist, and theologian Abū Hāmid al-Ghazzālī ("AI-Ghazali"). Al-Ghazali is one of the most influential and popular of the classical scholars of Islam, whose impact and appreciation is felt in the East and West, both within Islam and without. He applies the golden rule in various formulations as an axis around which great themes of religion are surrounded: God, purity of heart, justice, compassion, altruistic love, goodwill, human brotherhood, and neighborliness. Four texts are examined with specific attention paid to his most famous work, lhyö' 'Ulüm al-Din.
\end{abstract}

\section{KEYWORDS}

Islamic ethics; interfaith dialogue; comparative religion; theology and philosophy

\section{Background}

The ethics of reciprocity, popularly known as the "golden rule," is any moral dictum that encourages us to treat others the way we want to be treated. The rule appears in a variety of forms and contexts, in different religions, philosophies, and peoples widely separated by time, place, and language, to the degree that it appears to be a nearly universal maxim among humankind (Hertzler, 418). It is central to theistic religious ethics, as well as secular philosophical ethics, being justified on the basis of scriptural authority or reason or both. It is expressed in both positive formulations ("do unto others ...") and negative formulations ("do not do unto others ..."). Not surprisingly, the rule is stated or implied in Islam's canonical texts, as well as the writings of later Muslim theologians, philosophers, and mystics (Neusner and Chilton, Golden Rule, 99).

Religions, and indeed worldviews more generally, invariably include some kind of component that informs believers and practitioners of what they should or should not do. For our purposes, the golden rule fits within the ethical dimension of the

CONTACT Justin Parrott@justin.parrott@nyu.edu ENew York University Abu Dhabi, Saadiyat Island, PO Box 129188, Abu Dhabi, United Arab Emirates.

Published with license by Taylor \& Francis. @ Justin Parrott 
phenomenological study of religion (Smart, 11). The rule often appears as a summarizing principle of good conduct, as the supreme moral principle of right action between human beings. Not always to be understood too literally, it functions more as a method of reasoning in a process of moral, emotional, and spiritual development. Yet despite the different formulations, wordings, and contexts in which the rule appears across religions and traditions, there is enough continuity in meaning and application to justify describing the ethics of reciprocity as the golden rule, even though it is not explicitly referred to as such in classical Islamic or other religious texts (Wattles, 5).

Because of the near universality of the golden rule, it has come to play an important role in interfaith dialogue with Muslims. In October 2007, 138 prominent Muslim scholars and intellectuals signed an open letter entitled "A Common Word Between Us and You," asserting that Islam and Christianity, at their core, share the twin commandments to love God and to love your neighbor (Volf, Ghazi, and Yarrington, 3). The title of the letter was inspired by a verse from the Qur'ān, "Say, 'People of the Book, let us arrive at a statement that is common to us all [kalimah sawä']," (3:64) (Haleem, 59). The letter drew responses and publications from hundreds of intellectuals of Christian, Muslim, and Jewish backgrounds. These initial conversations moved beyond polite religious diplomacy to encompass detailed discussions of mutual global challenges such as climate change, human rights, and economic development (El-Ansary and Linnan, 7-11).

Within this context, an understanding and appreciation of the work of past sages and luminaries in the world's great religious traditions can help us find more common ground and insight for the present. One such Muslim scholar who relied heavily upon the golden rule is Abū Hāmid al-Ghazzālī (d. 1111), hereafter referred to as Al-Ghazali, one of the most influential Muslim scholars who ever lived. He was a jurist, theologian, mystic, and ethicist best known for his confrontation with the philosophers and the publication of his spiritual masterpiece Ihy a' 'Ulūm al-Dīn, the "Revival of the Religious Sciences." Sunni historian and biographer Al-Dhahabi (d. 1348) refers to Al-Ghazali as an "ocean" of knowledge and praises him with the honorific title "proof of Islam" (hujjat al-Islām) (al-Dhahabī, 19: 322). Yet his impact extends beyond his own friendly Sunni circles. Fayd al-Kāshī (d. 1680), also known as al-Kāshānī, was a prolific Shi' ite theologian and philosopher who wrote a multivolume "refinement" of the Ihya' to bring its spirituality and ethics in line with Shi' ite theology. Even many historians and scholars in the West admire Al-Ghazali's intellectual achievements, such as the late W. Montgomery Watt, "Al-Ghazali has sometimes been acclaimed in both East and West as the greatest Muslim after Muhammad, and he is by no means unworthy of that dignity" (Faith and Practice, 14).

$\mathrm{Al}$-Ghazali applies the golden rule as an axis around which great themes of religion are surrounded: God, purity of heart, justice, compassion, altruistic love, goodwill, human brotherhood, and neighborliness. Many of these themes are common to theistic religions and non-theistic philosophies. By examining them in relation to Al-Ghazali's use of the golden rule, we will find much material with which to inspire greater mutual understanding between Muslims and non-Muslims. 


\section{Al-Ghazali and the golden rule}

Al-Ghazali's ethical philosophy begins with God, a recognition of the nature of the soul, its origin, its purpose, its return after death, and its ultimate destination in either eternal happiness or damnation in the afterlife (Abul Quasem, 43). The aim of humankind ought to be a harmonious relationship with God that leads to heavenly paradise in the hereafter; the means ought to be rigorous inward character development coupled with outward acts of pious devotion and social duty. His is very God-centered ethics in which divine revelation takes precedence over, but does not entirely negate, independent moral reasoning (Hourani, 166).

Within this framework, Al-Ghazali finds the golden rule as implicitly deduced from the very essence of God's being. In his treatise on the attributes of God, he lists ninety-nine names of God, according to his count, along with counsel for worshipers to properly act upon the implications of God's names.

Al-Wadùd is the name for God in the Qur'ān that expresses God's love, care, and mercy: "But He is the Most Forgiving, the Most Loving," (85:14) (Haleem, 591). As part of God's nature, Al-Ghazali understands divine love to be the Creator's desire to benefit his creation:

Al-Wadūd-The Loving-kind-is one who wishes all creatures well and accordingly favors them and praises them. In fact, love and mercy are only intended for the benefit and advantage of those who receive mercy or are loved; they do not find their cause in the sensitiveness or natural inclination of the Loving-kind One. For another's benefit is the heart and soul of mercy and love and that is how the case of God-may He be praised and exalted-is to be conceived: absent those features which human experience associates with mercy and love yet which do not contribute to the benefit they bring (Ninety-Nine Beautiful Names, 118-19).

If God wishes benefit for all his creatures, then it logically follows that a worshiper should also wish benefit for God's creatures in accordance with the golden rule:
One is loving-kind among God's servants who desires for God's creatures whatever he desires for himself; and whoever prefers them to himself is even higher than that. Like one of them who said, 'I would like to be a bridge over the fire [of hell] so that creatures might pass over me and not be harmed by it.' The perfection of that virtue occurs when not even anger, hatred, and the harm he might receive can keep him from altruism and goodness (Ninety-Nine Beautiful Names, 119).

The positive formulation of the golden rule in this passage uses broad and inclusive language; one ought to desire for creatures ( $a l-k h a l q$ ) what he or she desires for themselves. It can be inferred that the rule applies to unbelievers in the sense that a Muslim should desire their salvation. The worshiper sets him or herself equal to others as far as goodwill is concerned. Greater than this virtue, however, is the practice of altruism (al-ithār), a word that conveys the sense of preferring others over one's own self (taqdìr al-ghayr 'alā al-nafs) (Altruism in World Religions, 74). One should desire to save others from damnation in the afterlife to the point that one endures harm from others for their own benefit. 
Golden rule reasoning to Al-Ghazali involves imaginative role reversal, or putting yourself in another's shoes, but he also relates the rule to one's relationship with God; one ought to serve God in the way one wishes his own servant would serve him. In a letter to one of his young disciples, he lists four things the disciple must do; the first two relate to the golden rule:

[The first is] that you make your relations with God the Exalted such that were a servant of yours to behave thus with you, you would be content with him and not weary of liking him, nor get angry. Whatever would dissatisfy you for yourself on the part of this hypothetical servant of yours, should dissatisfy you also for God the Exalted, and He is actually your Lord!

[The second is] whenever you interact with people, deal with them as you would wish yourself to be dealt with by them, for a worshiper's faith is incomplete until he wants for other people what he wants for himself (Letter to a Disciple, 56).

In this passage, one can hear an echo of the famous declaration in Luke 10:27 to "love the Lord your God with all your heart, and with all your soul, and with all your mind; and your neighbor as yourself" (New Oxford Annotated Bible, 1851). Like Jesus of Nazareth, Al-Ghazali mentions both the vertical God-centered dimension of religion and the horizontal human-centered dimension, one after another. He also uses inclusive language here again, advising his disciple to love for "the rest of people" (sā'ir al-nās) what he loves for himself.

As the purpose of life to Al-Ghazali is ultimate salvation with God, the appropriate means of this goal is to develop a righteous inward disposition and to purify the heart from spiritual diseases. The positive character traits (maḥāsin al-akhlāq) described in the Qur'ān are the criterion against which a person should measure his or her spiritual health. When it comes to the hadith traditions, the first tradition to be listed by Al-Ghazali as a sign of good character is the saying of the Prophet, "The believer loves for his brother that which he loves for himself" (On Disciplining the Soul, 68).

If the golden rule is an affirmative good character trait, then it can also be understood in relation to its opposite manifestations in the forms of destructive vices. Envy, according to Al-Ghazali, is the desire to have God's favor taken away from those who have been blessed by worldly fortunes; in other words, a desire to see harm done and loss incurred. It is the antithesis of the golden rule. As such, the worshiper must purge his or her heart of these evil feelings:

The envier is one who is distressed by God Almighty's bestowal of blessings from the treasures of his omnipotence upon a servant among his servants, such as knowledge, wealth, love in the hearts of people, or any kind of fortune, to the point that he loves for them to be taken away.... Rather, the worshiper will not reach the reality of faith as long as he does not love for all Muslims what he loves for himself. Rather, he should join with the Muslims for better or for worse. For the Muslims are like a single structure whose parts strengthen each other, or as a single body; if one of its limbs complains, the entire body complains (Bidāyat al-Hidàyah, 131). 
The parable of the faith community as a single building or body conveys the golden rule in implicit but understandable terms; everyone in the community is like part of one's own self and should be treated as one's self.

Two other sins of the heart, arrogance (al-kibr) and self-pride ('izzat al-nafs), he condemned for their contradiction with the golden rule. In a particularly rhetorical passage, Al-Ghazali denounces self-pride as a major obstacle that prevents Muslims from acquiring a number of virtues:

Indeed, [arrogance] becomes a veil over Paradise as it sets up a block between the servant and the character traits of the believers entirely. These character traits are the gates of Paradise, and arrogance and self-pride close all of these gates as he will not be able to love for the believers what he loves for himself while within him is something of pride. He will not be able to be humble, although it is the head character trait of the God-fearing, while within him is pride. He will not be able to leave malice while within him is pride. He will not be able to always speak the truth while within him is pride. He will not be able to leave anger while within him is pride. He will not be able to suppress his rage while within him is pride. He will not be able to leave envy while within him is pride. He will not be able to give kind advice while within him is pride. He will not be able to accept advice while within him is pride (Ihyä' 'Ulüm al-Dìn, 6: 491-92).

Purity of heart and soul is the theme in these two passages, as well as the greater third and fourth books of the Ihyā', in which he details methods for overcoming destructive vices (muhlikāt) and procuring salvific virtues (munjiyāt). Al-Ghazali discusses the inward dimensions of religion and their outward manifestations in separate sections of his works, but he often intertwines and connects them as they are not mutually exclusive subjects. Purity of heart must necessarily lead to the fulfillment of religious and social duties.

In several sections of the Ihyä', Al-Ghazali applies the golden rule to a number of social situations. In the quest for spiritual knowledge and truth, he finds a role model in Imām al-Shāfi'i (d. 820). Al-Shāfi'ì is best known for founding the legal school that bears his name and to which Al-Ghazali adhered. He was also known for his penetrating and successful debates with the scholars of other schools of thought. The key to this success, recounted by Al-Ghazali, was his pure intention and goodwill toward his opponents:

Al-Shāfi'ì, may God be pleased with him, said: I never debated anyone and loved for him to be wrong. And he said: I never spoke to anyone except that I loved for him to be guided, to be given direction, to be supported, and for the protection of God Almighty to be over him and preserve him. And I never spoke to anyone and cared whether God clarified the truth on my tongue or his tongue (Ihyä' 'Ulüm al-Dīn, 1: 99).

Al-Ghazali draws upon this spirit when he discusses the determents of excessive debate and intra-Muslim polemics. One of the pitfalls of the type of debating he criticized is that it causes bad will between opponents and conflicts with the golden rule:

And among [the evils of polemics] is joy by what is bad for people and despair by their happiness. Those who do not love for their brother Muslim what they love for themselves are far away from the character of the believers. For all who seek to boast by the display 
of superiority will inevitably be pleased by what is bad for his peers and rivals, those who seek to surpass his superiority. The hatred between them is like that between co-wives (Ihyā' 'Ulüm al-Dìn, 1: 173).

The activity of rival scholarship, then, is spiritually deficient unless it is done with good intentions and manners. Theological engagement ought to be done with the benefit of others in mind, not merely the desire to prove one's position correct.

After making this point in the beginning of the Ihy $\bar{a}^{\prime}, \mathrm{Al}-\mathrm{Ghazali}$ invokes the golden rule several times again when discussing duties towards various members of society. When it comes to trade and business, the rule serves as a catch-all principle to cover every situation of buying and selling:

All by which the dealer harms others is injustice. Indeed, justice is to not harm his brother Muslim and the entire standard for it is that he should not love for his brother except what he loves for himself. For if anything in his own dealings would cause hardship for himself and heaviness over his heart, then he should not deal with others the same way. Rather, he should consider his own money (dirhams) equal to the money of others.

Some of them said, 'Whoever sells his brother something for a dirham and he would not buy it himself except for five-sixths of a dirham (khamsah dawāniq), then he has departed from the good will with which he has been commanded in his dealings and he has not loved for his brother what he loved for himself'. This is the whole of it (Ihyā' 'Ulūm al-Dìn, 3: 292).

On this basis, he goes on to prohibit a trader from hiding the defects in a piece of merchandise. The Prophet's companions took a pledge with him to show sincere goodwill towards every Muslim, a pledge in which was implied adherence to the golden rule with others:

They understood it is part of sincerity (al-nash) that one should not be pleased for his brother to have except what pleases himself. They did not believe it was [merely] virtuous and an increase in [spiritual] ranks. Rather, they believed it was a condition of Islam within their pledge to him (Ihyā' 'Ulūm al-Dìn, 3: 296).

The trader should be more concerned with the afterlife and less involved with the affairs of this world. Al-Ghazali advises him to have a good and pure intention, refrain from begging, restrain his greed, and "let him intend to show good will to the Muslims and that he loves for the rest of creation (sa'ir al-khalq) what he loves for himself. Let him intend to follow the way of justice and benevolence in his dealings as we have mentioned" (Ihyya' 'Ulūm al-Dìn, 3: 323). Al-Ghazali again uses broad language in this formulation of the golden rule that could include people of other faiths, as "God has commanded justice and benevolence to one and all" (Ihyà' 'Ulüm al-Din, 3: 308).

Further along in the Ihya', Al-Ghazali has a detailed discussion of the good conduct, rights, and duties related to specific social groups. The first, most intimate group consists of those in a bond of brotherhood and friendship for the sake of God, for which he lists ten duties (Abul Quasem, 212). Among them is the duty to cover the friend's faults and to keep their secrets: 
Know that the faith of a person is not complete as long as he does not love for his brother what he loves for himself. The least degree of brotherhood is that he treats his brother as he would love to be treated by him. No doubt, he expects him to cover up his defects and to be silent about his faults and shortcomings. Were he to display the opposite of what he expected, his anger and rage for him would be severe. How far away from fairness he would be if he expected from him what he himself divulged and determined not to do for his sake! (Ihyä' 'Ulüm al-Dìn, 4: 88-89).

Indeed, the least degree of brotherhood is to apply the golden rule in a way that makes friends equal. Part of that equality between friends is to safeguard and defend each other's reputations within the bounds of reasonable justice; selfless and altruistic love, however, is another degree above it.

Backbiting, or speaking ill about another in his or her absence, is likewise a violation of the golden rule. Al-Ghazali reports the saying of the second-generation scholar Mujāhid, "Do not mention your brother in his absence except how you would love for him to mention you in your absence." And he quotes another unnamed righteous person who said, "My brother is not mentioned to me except that I imagine myself in his place, so I say about him what I would love to be said about me." Hence, Al-Ghazali concludes, "And this is true Islam: it is that he does not view his brother except how he views himself”' (Ihyā' 'Ulūm al-Dìn, 4: 102-03).

Later on in the Ihyä', while discussing the spiritual cure for backbiting, he says, "If he is not pleased to be backbitten, then he should not be pleased for others what he is not pleased with himself. So these are the comprehensive treatments" (Ihyā' 'Ulüm al-Dìn, 5: 525). The golden rule is again an all-inclusive principle for righteous behavior, in this case as a guide for avoiding the many sins of the tongue.

Supplication and prayer on a friend's behalf is another right of brotherhood that is rooted in the golden rule:

[Among his rights are] prayer for his brother in his life and after his death for everything that he loves for himself, his family, and everything related to him. Thus, you pray for him as you pray for yourself, without distinction between yourself and him. Indeed, your prayer for him is a prayer for yourself in reality.

The reason one's prayer for another is the same as prayer for himself is entirely theological. He cites the saying of the Prophet, "When a man prays for his brother behind his back, the angel says: And for you likewise" (Ihyä' 'Ulūm al-Dìn, 4: 121). In this instance, his referral to the golden rule is justified by his belief in the behavior of angels, rather than by any philosophical or rational reason.

Al-Ghazali discusses the duties of friendship in another treatise entitled the Beginning of Guidance (al-Bidāyah al-Hidāyah). He concludes his list of duties by noting that they can all be summarized by the golden rule:

On the whole, he should treat him [his companion] the way he would love to be treated by him. For whoever does not love for his brother what he loves for himself, then his brotherhood is hypocrisy and the ruinous consequence will be against him in the world and in the afterlife (al-Bidāyah al-Hidāyah, 163). 
After brotherhood and friendship for the sake of God comes the wider circle of Muslims. In the Ihyā', Al-Ghazali enumerates twenty-seven rights and corresponding duties that Muslims have toward one another (Abul Quasem, 214). Among the rights of a Muslim summarized at the beginning of this section are "that you love for him what you love for yourself, and you hate for him what you hate for yourself" (Ihyā' 'Ulüm al-Dìn, 4: 150). This rendering of the golden rule by Al-Ghazali contains both a positive and negative formulation. In the Persian language abridgement of the Ihya', the Alchemy of Happiness (Kimiya al-Sa'dat), Al-Ghazali also lists this as the first right of a Muslim, although he only uses the negative formulation "that one not like for another Muslim that which one does not like for himself." (Alchemy of Happiness, 1: 342). A following passage in the Ihyā' supports this right to golden rule treatment with a reference to the Prophet's parable of the community as a body, "The likeness of the believers in their love and compassion is that of a body; if a limb of it is afflicted, the entirety responds with fever and sleeplessness" (Ihyä' 'Ulüm al-Din, 4: 151).

Further down the list of rights, Al-Ghazali mentions the golden rule again in the context of fairness, "And among [these rights] is that he has a sense of fairness to people from himself and he does not treat them except in the way he would love to be treated by them." He justifies this right with the saying of the Prophet, "Whoever is pleased to be delivered from Hell and admitted to Paradise, then let him meet his end while he bears witness there is no god but God and Muhammad is the messenger of God, and let him treat people the way he would love to be treated by them" (Ihyā' 'Ulüm al-Dìn, 4: 163). In the following passage, he cites another golden rule hadith tradition to support the right of a Muslim to sincere advice and goodwill (al-nasịhah) and the corresponding duty of other Muslims to endeavor for each other's happiness (Ihyā' 'Ulūm al-Dīn, 4: 197).

The last and largest social grouping which has rights are neighbors, including Muslims and non-Muslims. Al-Ghazali explicitly says that even "the idolater" has been given neighborly rights by the Prophet. He conceives of these rights not only as negative rights (i.e., avoidance of harm), but as positive rights as well, "Know that it is not only the right of the neighbor to be free from harm. Rather, harm should be endured.... It is also not enough to endure harm. Rather, he must be gentle and offer charity and good conduct" (Ihyā' 'Ulūm al-Dīn, 4: 212, 215). In other words, a Muslim should not merely avoid injustice; it is also an obligation to offer proactive kind treatment to neighbors.

To illustrate this point, he tells a story of the famous Persian author and convert to Islam 'Abd Allāh Ibn al-Muqaffa' (d. 757):

Ibn al-Muqaffa' heard that a neighbor of his was selling his house because of a debt that burdened him. He was sitting in the shade of his house and he said, 'I have not respected the sanctity of the shade of his house if he sells it to fulfill the debt.' Thus, [Ibn al-Muqaffa'] paid the price of the house to him and told him not to sell it.

And one of them complained about the abundance of rats in his house. It was said to him, 'If only you had a cat!' So [Ibn al-Muqaffa'] said, 'I am afraid that the rats would hear 
the voice of the cat and flee to the house of the neighbors, for then I would have loved for them what I do not love for myself' (Ihyā' 'Ulüm al-Dìn, 4: 215-16).

Ibn al-Muqaffa' shows an uncanny concern for the well-being of his neighbors, based upon golden rule reasoning, to the point of enduring harm at their expense. We can understand from this passage that the golden rule to Al-Ghazali applies to all neighbors regardless of their religious beliefs.

Nevertheless, golden rule reasoning becomes more difficult when two or more moral agents or priorities exist in a given situation. Al-Ghazali acknowledges the realities of warfare and the imperative to resist injustice and to defend the innocent. He denies benevolence to "all those who disobey God with transgressive disobedience to others," or, in other words, those who violate human rights as understood by him. If only one variable or agent is involved in the moral equation, the golden rule applies even to those who oppress and cause personal harm. However, if multiple variables are involved in the moral equation, Al-Ghazali defers golden rule treatment to the one whose rights have been violated:

And to pardon one who does wrong and to be good to one who does evil is among the character traits of the truthful. Indeed, benevolence may be shown to the one who wrongs you, but as for one who harms another person and disobeys God by it, then he should not be shown benevolence because benevolence to the wrongdoer is evil to the wronged [victim]. And the right of the wronged is to be considered first, and to strengthen [the victim's] heart by turning away the wrongdoer is more beloved to God than strengthening the heart of the wrongdoer. As for when you yourself are wronged, then benevolence, pardon, and excuse is within your right (Ihyā' 'Ulüm al-Dìn, 4: 47).

The golden rule is not necessarily negated by Al-Ghazali's prescription to show enmity for the sake of God to an oppressor. The intention of this enmity is not the satisfaction of vengeance for vengeance's sake. As he discusses elsewhere, one's motivation should be entirely to approach God through obedience, "He who aims to draw near to God (Exalted is He) is 'sincere"' (Al-Ghazali on Intention, 58). Rather, he views the situation through a hierarchy of rights; the oppressed need for their rights to be restored before clemency is shown to the oppressor. The motivation behind enmity for the sake of God must be pure towards this end.

For this reason, Al-Ghazali warns his readers to critically examine their intentions whenever they think showing enmity for the sake of God is appropriate. Enmity should be out of a concern for rights, the benefit of the wronged, and the welfare of society as a whole according to what God desires. Hostility in God's name that is motivated out of envy, pride, arrogance, or hateful malice, all of which he has condemned, is illegitimate. On the other hand, even kindness and gentleness can be blameworthy if they arise from a flawed intention and produce harmful results:

For in gentleness and looking with the eye of mercy to the creation is a type of humility, and in harshness and turning away is a type of rebuke. The one to consult is the heart. So whatever he sees is inclined to his caprice and in accordance with his [sinful] nature, then the first thing is to oppose it; whether his contempt and harshness had been out of pride, vanity, enjoyment of showing superiority and taking liberty with righteousness, and whether his gentleness had been out of flattery, to persuade [the wrongdoer's] heart by it to 
arrive at some purpose, or the fear of the effect of his disaffection and aversion on his status or wealth by a suspicion likely or unlikely. And all of that is due to the signals of Satan and is far from the deeds of the people of the Hereafter (Ihyä' 'Ulüm al-Dìn, 4: 56).

These passages highlight the challenge of golden rule reasoning as it relates to situations of just war and legal punishment. Yet the rule itself is not nullified by these harsh worldly realities; it simply is distributed first to those who most deserve it, either a wronged individual or society at large. Wisdom and subtle introspection are required to act within a complicated moral dilemma for which there are no easy answers. The insights of the sages are necessarily subjective and not always formulaic in juristic terms, which makes golden rule reasoning in these cases less of a philosophical science and more of a high spiritual art.

\section{Conclusion}

Al-Ghazali's strident theological ethics is underpinned by the golden rule, which he often uses as a summarizing principle of moral guidance in a variety of contexts. He relates the rule to a number of other ethical themes that are prominent in both classical and modern Islamic literature, the same themes that occur in many other religious and philosophical traditions. Perhaps most important for interfaith relations with Muslims is his more or less explicit application of the golden rule to peaceful non-Muslims, notwithstanding the unfortunate circumstances of war and resistance to injustice. The implied equality in Al-Ghazali's golden rule ethics provides a theological basis within classical Islam for a common understanding of basic, modern human rights and interfaith cooperation on mutual global challenges like climate change and fair economic development. Appreciation for Al-Ghazali's golden rule may also help non-Muslims better empathize with their fellow Muslim citizens and potentially reduce the grassroots hostility towards Islam that is the product of Internet misinformation and heated political rhetoric.

\section{Works cited}

Abul Quasem, Muhammad. The Ethics of al-Ghazali: A Composite Ethics in Islam. Petaling Jaya: Quasem, 1975.

Coogan, Michael D., Marc Z. Brettler, Carol A. Newsom, and Pheme Perkins. The New Oxford Annotated Bible: With the Apocrypha. New York: Oxford University Press, 2010.

al-Dhahabī, Muhammad A., and Shu’ayb Arnā'ụt;; et al. Siyar A’lām al-Nubalā'. Dimashq: al-Risālah al-'ālmiyah, 2014.

al-Ghazzālī, and Anthony Shaker. Al-Ghazali on Intention, Sincerity and Truthfulness: [Kitāb al-Niyya wal'l-Ikhlās wa'l Sidq] Book XXXVII of the Revival of the Religious Studies [Ihyä' 'Ulūm al-Dìn]. Cambridge, UK: Islamic Texts Society, 2013.

al-Ghazzālī, Jay R. Crook, and Laleh Bakhtiar. The Alchemy of Happiness (Kimiya al-Saadat). Chicago, IL: Great Books of the Islamic World, 2008.

al-Ghazzālī, and 'Abd H. M. Darwīsh. Bidāyat al-Hidāyah. Bayrūt: Dār Șādir, 1998.

al-Ghazzālī, and W. M. Watt. The Faith and Practice of Al-Ghazālì. London: G. Allen and Unwin, 1953. 
al-Ghazzālī, and 'Abd -Q. S. 'Aydarūs. Ihyyā' 'Ulūm al-Dīn. Jiddah: Dār al-Minhāj lil-Nashr wa-al-Tawzì', 2011.

al-Ghazzālī, and Tobias Mayer. Letter to a Disciple: Ayyuhā'l-Walad. Cambridge, UK: Islamic Texts Society, 2005.

al-Ghazzālī, David B. Burrell, and Nazih Daher. The Ninety-Nine Beautiful Names of God: AlMaqsad al-Asnā fì $\underline{\text { S }}$ harh Asmā' Allāh al-Husnā;. Cambridge, UK: Islamic Texts Society, 2011.

al-Ghazzālī, and Timothy Winter. On Disciplining the Soul [Kitāb Riyādat al-Nafs], \& On Breaking the Two Desires [Kitäb Kasr al-S_h_ahwatayn]: Books XXII and XXIII of the Revival of the Religious Sciences [Ihyā' 'Ulūm al-Dìn]. Cambridge, UK: Islamic Texts Society, 1995.

El-Ansary, Waleed A., and David K. Linnan. Muslim and Christian Understanding: Theory and Application of "a Common Word." New York: Palgrave Macmillan, 2010.

Haleem, M. A. S. A. The Quran: English Translation with Parallel Arabic Text. Oxford: Oxford University Press, 2010.

Hertzler, J. O. “On Golden Rules.” The International Journal of Ethics. 44.4 (1934): 418-36.

Hourani, George F. Reason and Tradition in Islamic Ethics. Cambridge: Cambridge University Press, 1985.

al-Kāshī, Faỵ̣ M. M., and 'Alī A. Ghaffārīj. Al-Mahajjah al-Baydā' fì Tahdhīb al-Ihyā̄'. Tihrān: Maktabat al-Ṣadūq, 1939.

Neusner, Jacob, and Bruce Chilton, eds. Altruism in World Religions. Washington, D.C.: Georgetown University Press, 2005.

Neusner, Jacob, and Bruce Chilton, eds. The Golden Rule: The Ethics of Reciprocity in World Religions. London: Continuum, 2008. 99.

Smart, Ninian. Dimensions of the Sacred: An Anatomy of the World's Beliefs. Berkeley: University of California Press, 1996.

Volf, Miroslav, bin M. Ghazi, and Melissa Yarrington, eds. A Common Word: Muslims and Christians on Loving God and Neighbor. Grand Rapids: W. B. Eerdmans Pub. Co., 2010.

Wattles, Jeffrey. The Golden Rule. New York: Oxford University Press, 1996. 